\title{
Discussion on innovation of ideological and political theory course teaching at higher vocational schools based on the concept 'combination of general education and professional education'
}

\author{
Xiye Xu \\ Tianjin Vocational Institute, Tianjin, 300410, China
}

Keywords: Combination of general education and professional education; Innovation; Ideological and political Course at higher vocational schools; Teaching

\begin{abstract}
Pertinence and effectiveness of teaching of ideological and political theory course has been a goal that higher vocational schools work hard to pursue but cannot be realized easily all the time. Being guided by the concept 'combination of general education and professional education', we may carry out innovation for teaching content, i.e., the combination that basic theory in textbooks will be retained and professional characteristic content will be expanded. Meanwhile, implement innovation for teaching process, i.e., relying on teaching content and combining cramming teaching and non- cramming teaching. Besides, carry out innovation for construction of teaching staff, i.e., combining professionalization of knowledge about ideological and political theory with extension of specialized knowledge. By reform and innovation, pertinence and effectiveness of teaching of ideological and political theory course can be realized.

Opinions on Enhancing and Improving College Students' Ideological and Political Education Further issued by the Central Committee of the Communist Party of China and the State Council proposes we should work hard to improve teaching situation of ideological and political theory course in a few years obviously. This not only reflects the country pays much attention to teaching of ideological and political course but also shows teaching effect of ideological and political course is not ideal enough at present, the degree to which higher vocational college students accept and approve ideological and political course is not high or effect of 'main channels' has not exerted sufficiently.

For this, the author combines his own practice about education and teaching and tries to put forward the teaching concept 'combination of general education and professional education', hoping to improve current status of ideological and political course teaching via innovation gradually, enhance attraction and influence of ideological and political course, drive effectiveness of teaching and make ideological and political course be a course that high vocational college students love sincerely, benefit all their life and remember perpetually.
\end{abstract}

I. Carrying out innovation for teaching content of ideological and political course based on the concept 'combination of general education and professional education', i.e., the combination that basic theory in textbooks will be retained and professional characteristic content will be expanded

Teaching content is source of life for ideological and political course. Ideological and political course can show vigorous vitality only when teaching content is designed scientifically and selected reasonably. Three ideological and political courses established by higher vocational schools, including Ideological and Moral Cultivation and Fundamentals of Law, Introduction to Mao Zedong Thought and Theoretical System of Socialism with Chinese Characteristics and Situation and Policy, are state-compiled textbooks with abundant content, wide coverage and perfect system. However, this does not mean teaching should be carried out according to content in textbooks completely. The situation that content in textbooks need be converted into teaching content has become a consensus. The key to problems lies in how to convert it reasonably to make students more willing to accept it 
and realize teaching objectives of ideological and political course. The author deems that we should be guided by the concept 'combination of general education and professional education'. 'General education' directs at all students and will retain basic theoretical content in textbooks, while 'professional education' aims at students from different majors and content extension reflects content with different professional features.

Firstly, basic theory and spirit in textbooks must be kept. For instance, basic theory like Marxism, socialist ideology, socialist core value system, Reform and Opening-up, Scientific Outlook on Development, patriotism, ideal and faith, basic moral cultivation and legal accomplishment cannot be changed or deleted. The reason for this is shown as follows. On the one hand, although theory itself is abstract and boring, it is summarization and refinement of history and reality, which comes from practice and guides practice. 'Classical theory itself contains endless charm. Textbook system about core courses of ideological and political theory reflects specific perspectives of theoretical research and content arrangement, contains basic content of Marxist theory, new progress in localization of Marxism in China, development road of modern China, the latest research achievements of socialist theory system with Chinese characteristics and basic requirements of political and social life for individuals' ideology, morality and legal cultivation and shows features and level of research on Marxism in contemporary China' [1]. On the other hand, this ensures students approve leadership of Chinese Communist Party and firms their demands for socialism with Chinese characteristics.

Secondly, on the basis that basic theory is kept firm, design different teaching schemes and teaching emphasis and form individualized teaching content of specific majors or major groups according to different requirements for training of professional talents and in combination with students' majors, industrial features and demands of career development in future. Extension of individualized teaching content should focus on selection of individualized teaching cases. For all students at higher vocational schools, basic theoretical knowledge of ideological and political course is the same. The key lies in which teaching cases should be selected to make students from different majors feel and approve ideological and political course in order that the teaching objective that students' comprehensive quality is improved can be realized.

This thesis takes the course Ideological and Moral Cultivation and Fundamentals of Law at Tianjin Vocational University where the author works for example, focuses on objective of employment-oriented talent training and combines with students' professional needs. First of all, it integrates textbook content to form eight special subjects, as shown in Table 1.

\section{Table 1}

\begin{tabular}{|l|l|}
\hline $\begin{array}{l}\text { Special } \\
\text { subject } \\
1\end{array}$ & $\begin{array}{l}\text { How do students adapt to college (higher vocational college) life and start } \\
\text { their jobs as soon as possible? }\end{array}$ \\
\hline $\begin{array}{l}\text { Special } \\
\text { subject } \\
2\end{array}$ & How do students establish occupational values and realize ideals? \\
\hline $\begin{array}{l}\text { Special } \\
\text { subject } \\
3\end{array}$ & $\begin{array}{l}\text { How do students cognize the relationship between patriotism and vocational } \\
\text { ability correctly? }\end{array}$ \\
\hline Special & How do students deal with the relationship between themselves and the \\
\hline
\end{tabular}




\begin{tabular}{|l|l|}
\hline $\begin{array}{l}\text { subject } \\
4\end{array}$ & society? \\
\hline $\begin{array}{l}\text { Special } \\
\text { subject } \\
5\end{array}$ & How can we improve our professional quality? \\
\hline $\begin{array}{l}\text { Special } \\
\text { subject } \\
6\end{array}$ & How do we cognize love and marriage correctly? \\
\hline $\begin{array}{l}\text { Special } \\
\text { subject } \\
7\end{array}$ & $\begin{array}{l}\text { How can we enhance legal consciousness and be employees observing } \\
\text { laws? }\end{array}$ \\
\hline $\begin{array}{l}\text { Special } \\
\text { subject } \\
8\end{array}$ & \begin{tabular}{l} 
How can students change to be 'social workers'? \\
\hline
\end{tabular}
\end{tabular}

The eight special subjects not only keep basic theory content in textbooks but also reflect the vocational feature that they combine with majors. Secondly, teachers integrate cases related to majors with each special subject according to professional requirements of students from different majors and post demands and carry out 'special-favor' teaching. For instance, when teachers teach content about patriotism, they may introduce the case to students majoring in Tourism Management, i.e., 'as a common tour guide from Xi'an guided Clinton former president of America, he not only maintained dignity of our country but also obtained a chance of promotion by virtue of his professional ability and smart answers to the president's questions'. In doing so, teachers may guide students to master the relationship between patriotism and career. Aiming at students majoring Biotechnology, teachers may use a case about hard work of Yuan Longping 'father of hybrid rice' to encourage students study hard, master professional skills and rely on their ability to realize pursuit for patriotism. Of course, not all teaching content can be developed by 'special-favor' teaching. For some content, such as love and marriage and social morality, the same content and cases can be taught to all students via a public teaching method.

\section{Implementing innovation for teaching process based on the concept 'combination of general education and professional education', i.e., relying on teaching content and combining cramming teaching and non- cramming teaching}

Teaching content of the three ideological and political courses of higher vocational colleges is not hard to understand. However, teachers need internalize knowledge and content into students' ideas and externalize them into specific actions via teaching. This cannot be realized by telling conclusions simply. Indeed, it is necessary for teachers to design and arrange teaching process carefully. Design and arrangement about teaching process are mainly reflected by selection and application of teaching methods. In fact, teaching process is the procedure during which various teaching methods are used to decompose and integrate teaching content to make students willing to accept teaching content. The author thinks that teachers should rely on teaching content and combine cramming teaching and non-cramming teaching to carry out teaching. 
Firstly, insist on cramming teaching for basic theoretical content of ideological and political course. This is a basic principle of Marxism. 'Consciousness of class struggle can only be infused to workers externally. To infuse political knowledge to workers, social democratic parties should go to all stratums of residents and distribute their groups to all aspects'. [2] P293 Although Lenin's principle that socialist consciousness must be infused externally was generated at the beginning of the 20th century when proletarian revolution of Russia was carried out, historical conditions of the period were much different from that in the period of socialist modernization and ideological characteristics of educational objects at present also change a lot, practice of Reform and Opening-up and progress of modernization construction prove that publicity of socialist ideology, interpretation about fundamental policy of a country and cultivation of qualified constructors and reliable successors for socialist cause cannot be separated from infusion about Marxist theory.

Implementing cramming teaching for higher vocational college students doe not use compulsory means to force students to accept Marxist theory since 'it will be non-effective but harmful to try to use administrative orders and compulsive methods to solve ideological problems and disputes' . [3] P762 Cramming teaching should be carried out on the premise that students are respected, give reasoning guidance with pertinence, convince students by reasoning, analyze basic theoretical knowledge profoundly, explain profound theory in simple language and enhance influence and persuasion of teaching. Cramming teaching may be developed by several methods, including explanation, report, persuasion and reading books. Explanation and reports mainly involve teachers' one-way impacts on students and basic theory of ideological and political course can be elaborated systematically. Conversation is two-way communication between teachers and students. Teachers should suit the remedy to the case and adapt measures to different people to give guidance according to different ideological conditions of students from different majors. Reading books means students use written language for self-teaching and book they read are usually recommended and required by teachers.

Secondly, individualized teaching content and cases combining with features of majors should focus on non-cramming teaching. The said non-cramming teaching is relative to cramming method. Methods except for cramming teaching are non- cramming teaching ones. Ideological and political course of colleges should not only cultivate qualified constructors and successors for socialist cause but also pay attention to students' students' subjectivity and promote their free and comprehensive development. Obviously, this task cannot be finished by relying on cramming teaching only. For individualized teaching content, non-cramming teaching should be a primary method. Non-cramming teaching is a way that passes through the whole process of ideological and political course teaching, which is divided into classroom non-cramming teaching and extracurricular non-cramming teaching.

Classroom non-cramming teaching methods mainly contain discussion, debate, speech and scenario simulation etc. Teachers should rely on designed teaching content and cases and use different methods for classroom teaching according to different majors of students. For example, in the special subject 'How can we enhance legal consciousness and be employees observing laws?' in the course Ideological and Moral Cultivation and Fundamentals of Law, teaches may organize students from different majors to play roles of moot courts according to different cases. In detail, students may play roles like accuser, indictee, attorney agent, judge, court clerk and bailiff. In doing so, students can not only master legal knowledge related to majors personally but also practice their strain capacity and communication skills.

Extracurricular non-cramming teaching mainly centers on practical teaching. Importance of practical teaching in ideological and political course teaching has been accepted by higher vocational schools and teachers. Thus, they have explored and tried it in practice by many methods. However, effectiveness is not satisfying. The main reason for this is that practical teaching is separated from students' majors and employment, which causes students' weak intention to participate. As a result, they just cope with it indifferently. Therefore, teachers should deign practical teaching projects related to majors and realize teaching by different methods according to students' various majors. 


\section{Carrying out innovation for construction of teaching staff based on the concept 'combination of general education and professional education': combining professionalization of knowledge about ideological and political theory with extension of specialized and industrial knowledge}

It is no doubt that innovation based on the concept 'combination of general education and professional education' puts forward higher requirements for ideological and political course teachers' quality and ability. Traditional teachers that only pay attention to research have failed to satisfy demands of higher vocational schools for talent cultivation and needs of students' for learning and growth. Thus, transition must be implemented to construct a group of teaching paying equal attention to research and application. On the one hand, ideological and political course teachers should improve their research ability constantly and become more professional with respect to mastery of theoretical knowledge about ideological and political course. The reason for this is that 'effectiveness of ideological and political course teaching cannot be improved if teachers do not master profound theory accurately or study textbooks deeply or are not good at combining theory with practice but pursue innovation of teaching methods blindly'. [4] On the other hand, ideological and political course teachers should pay attention to law of higher vocational education, learn industrial knowledge about students' majors and master features of majors and specific industries that are corresponding to majors as well as status and development trend of related industries in order to provide professional background for teaching that combines ideological and political course and professional courses and enhance teaching effectiveness. To achieve this, schools may try the following approaches: schools may distribute ideological and political course teachers to hold the post of head teachers or instructors at departments to learn students' features, life and ideological situation; ideological and political course teachers may take part in teaching and researching activities of professional course teachers to learn basic content of specialized courses and training objectives of professional talent; ideological and political course teachers may also start from majors to have social practice at enterprises and industries regularly to learn enterprises' demands for talent; they may also read books and magazines related to majors and pay attention to industry news and hot spots of the society, which are related to majors, in order to know the latest trend of majors and industries and integrate it with teaching of ideological and political teaching etc.

It is worth mentioning that this brings high pressure and challenge to ideological and political course teachers who undertake ideological and political course teaching of a whole school where teachers are insufficient undoubtedly. To meet challenges, we need achieve the following aspects. First of all, higher vocational schools should insist on the principle of humanistic care, introduce some talent, expand the group of ideological and political course teachers and reduce quantity of work tasks of ideological and political course appropriately. Secondly, schools may ask ideological and political course teachers to give 'contract-type' teaching. In another word, each teacher 'undertakes' several majors and he or she teaches students from such majors fixedly each year. This can not only reduce teachers' workload but also enable them to spend more time in studying majors they teach, deepen their comprehension about majors, improve the degree to which ideological and political course and majors are combined closely and strengthen influence and effectiveness of ideological and political course teaching. Thirdly, ideological and political course teachers should follow 'student-oriented' principle, denote themselves to work with excellent morality and quality, tough will and character, open and stable personality, wide interest an hobbies and full work enthusiasm and infect students by their personality charm.

\section{Acknowledgments}

This thesis is a task which is supported by the special funds for ideological and political project (Research and Practice about Innovation for Teaching of Ideological and Political Course at Higher Vocational Schools Based on 'Combination of General Education and Professional 
Education') of humanistic and social science at institutions of higher learning in Tianjin (project No.: 2011szk23) and the project leader is Xu Xiye.

\section{Reference:}

[1] Xu Rong. On supporting point and balance of theoretical teaching in ideological and political course [J]. Teaching and Research, 2013(1)96-101.

[2] Lenin. Lenin Selected Works (Volume 1) [M]. Beijing: People's Publishing House, 1960:293.

[3] Mao Zedong. Selected Readings of Mao Zedong’s Works (Volume 2) [M]. Beijing: People's Publishing House, 1986:762.

[4] Zhang Leisheng. Teaching of Marxist methodology and ideological and political theory course [J]. ideological and political theory course, 2011(9)21-24. 